\title{
Effective process safety management for highly hazardous chemicals
}

\author{
Piyanart Sommani ${ }^{1,3 *}$, Anchaleeporn Waritswat Lothongkum ${ }^{2,3}$, Panuwat Jumpasri², 3, ${ }^{4}$, Nichit Hongbin ${ }^{2}$ and Wasana \\ Kowhakul $^{5}$ \\ ${ }^{1}$ Department of Electrical Engineering, Faculty of Engineering, King Mongkut's Institute of Technology Ladkrabang, \\ Bangkok 10520, Thailand \\ ${ }^{2}$ Department of Chemical Engineering, Faculty of Engineering, King Mongkut's Institute of Technology Ladkrabang, \\ Bangkok 10520, Thailand \\ ${ }^{3}$ Chemical Engineering and Petrochemicals, The Engineering Institute of Thailand under H.M. the King's Patronage, \\ Bangkok 10310, Thailand \\ ${ }^{4}$ Disaster Prevention Criteria Bureau, Department of Disaster Prevention and Mitigation, Ministry of Interior, \\ Bangkok, 10300, Thailand \\ ${ }^{5}$ Department of Chemical Engineering, Faculty of Engineering,Fukuoka University, Fukuoka 814-0180, Japan
}

\begin{abstract}
Process safety management (PSM) has been a critical consideration in the plants that handle highly hazardous chemicals (HHCs), flammable gases and liquids. This article introduces PSM standard by OSHA's 29 CFR 1910.119. Further, it highlights an effective PSM for HHCs and provides PSM practices of the industries in Thailand. Effective PSM can prevent or mitigate catastrophic releases of HHCs which can cause health problems, fires, explosions, and fatalities. It is a disciplined framework for managing the integrity of operating systems, safety critical equipment (SCE) and safe work practices. Effective implementation and audits of PSM system and the continual improvement are important. It requires the industries to execute suitable leading and lagging process safety metrics. The inclusive and integrated PSM intents, human factors, good design principles, recognized and generally accepted good engineering practices (RAGAGEPs), engineering and administrative controls, and integrity of operating and maintenance practices are substantial key roles. It is important that the PSM system should be risk-based under the ALARP concept because hazards and risks are not equal, and there are multiple risks and consequences to consider. In summary, the PSM effectiveness depends on, for example, process safety metrics, management review, audit findings and particularly workforce involvement.
\end{abstract}

\section{Introduction}

Process safety management (PSM) is a disciplined framework for managing the integrity of operating systems and processes handling hazardous substances by applying good design principles, engineering, and operating practices [1]. PSM principles apply at facilities that manufacture, store, handle or use highly hazardous chemicals (HHCs). Unlike the occupational safety or personal safety that emphasizes on the prevention and mitigation of hazards causing adverse effects on employees' health and welfare such as slips, trips, and falls, process safety addresses on the prevention and mitigation of process hazards possibly resulting in the releases of chemicals or energy. Such hazards could ultimately result in serious impacts on human health, environmental damage, as well as loss of assets and production. The U.S. Department of Labor, Occupational Safety and Health Administration (OSHA) has promulgated 29 CFR Part 1910.119 Process Safety Management (PSM) of Highly Hazardous Chemicals. The standard integrates 14 elements to prevent or minimize the hazards and consequences from toxic, flammable, highly reactive, and explosive substances [2]. It applies to manufacturing industries, particularly those pertaining to chemicals, transportation equipment, and fabricated metal products. PSM applies to those industries that deal with any of more than 130 specific toxic and reactive chemicals in listed quantities of the standard; it also includes flammable liquids and gases in quantities of 10,000 pounds $(4,535.9 \mathrm{~kg})$ or more. To help prevent process safety incidents, an effective process safety management must be implemented. This article emphasizes on OSHA's 29 CFR 1910.119 Process

* Corresponding author: piyanart.so@kmitl.ac.th 
Safety Management for Highly Hazardous Chemicals [3] and discusses what the effective PSM system should be.

\section{OSHA'S PSM}

Engineers and personnel involved with HHCs can obtain PSM information from several sources. One of the useful sources is from OSHA, whose category of news and publications provided, e.g., Process Safety Management (OSHA 3132-2000), Process Safety Management Guidelines for Compliance (OSHA 3133-1994), Process Safety Management for Storage Facilities (OSHA 39092017) [4], and Chemical Process Hazards Analysis [5]. The intents of OSHA'S PSM are summarized in Table 1.

Table 1. OSHA's PSM Requirements (adapted from [4]).

\begin{tabular}{|c|c|}
\hline Elements & Requirements \\
\hline $\begin{array}{l}\text { Employee } \\
\text { Participation } \\
\text { (EP) }\end{array}$ & $\begin{array}{l}\text { Employers must develop a written plan } \\
\text { of actions to implement the employee } \\
\text { participation required by PSM. They } \\
\text { must support the employees to get } \\
\text { involve in developing and executing the } \\
\text { PSM programs, particularly in the area } \\
\text { of hazard identification and assessment. } \\
\text { Employees shall be able to access to } \\
\text { process hazard analyses and to all other } \\
\text { information required. }\end{array}$ \\
\hline $\begin{array}{l}\text { Process Safety } \\
\text { Information (PSI) }\end{array}$ & $\begin{array}{l}\text { Employers must complete a compilation } \\
\text { of written PSI related to the nature of the } \\
\text { chemical or flammable hazards involved, } \\
\text { process technology, and process } \\
\text { equipment before conducting any } \\
\text { process hazard analysis required by the } \\
\text { standard. All PSI must be kept up-to- } \\
\text { date. }\end{array}$ \\
\hline $\begin{array}{l}\text { Process Hazard Analysis } \\
\text { (PHA) }\end{array}$ & $\begin{array}{l}\text { Employers must perform PHA based on } \\
\text { risk-based to all covered processes. } \\
\text { According to the appropriate hazard } \\
\text { analysis method(s), a qualified team shall } \\
\text { identify and evaluate hazards, and } \\
\text { recommend the corrective or preventive } \\
\text { measures to prevent, mitigate, or control } \\
\text { hazards. All process hazard analyses } \\
\text { must be updated and revalidated based } \\
\text { on their completion date at least every } \\
\text { five years. }\end{array}$ \\
\hline $\begin{array}{l}\text { Operating Procedures } \\
\text { (OPs) }\end{array}$ & $\begin{array}{l}\text { Employers must develop and implement } \\
\text { written operating procedures, consistent } \\
\text { with PSI, that provide clear instructions } \\
\text { for safely conducting activities of all } \\
\text { operating phases of its operation } \\
\text { including safe work practices involved, } \\
\text { e.g., lock out/tag out, line breaking, } \\
\text { confined space in each covered process. } \\
\text { The employers must certify annually that } \\
\text { the operating procedures are current and } \\
\text { accurate. }\end{array}$ \\
\hline Training & $\begin{array}{l}\text { Employers must provide (1) initial } \\
\text { training to each employee, including } \\
\text { contractors, presently involved in } \\
\text { operating a process or a newly assigned } \\
\text { process in an overview of the process } \\
\text { and in its operating procedures, and (2) } \\
\text { refresher training at least every three } \\
\text { years or more often if necessary to } \\
\text { ensure that the employees and }\end{array}$ \\
\hline
\end{tabular}

\begin{tabular}{|c|c|}
\hline Elements & $\begin{array}{r}\text { Requirements } \\
\end{array}$ \\
\hline & $\begin{array}{l}\text { contractors understand and adhere to the } \\
\text { current operating procedures of the } \\
\text { process. }\end{array}$ \\
\hline Contractors & $\begin{array}{l}\text { PSM applies to contractors performing } \\
\text { maintenance or repair, turnaround, major } \\
\text { renovation, or specialty work on or } \\
\text { adjacent to a covered process. PSM } \\
\text { includes special provisions for } \\
\text { contractors and their employees to } \\
\text { emphasize the importance of everyone } \\
\text { taking care that they do nothing to } \\
\text { endanger those working nearby. The } \\
\text { contractor safety management programs } \\
\text { are responsibilities of both employers } \\
\text { and contractors. }\end{array}$ \\
\hline $\begin{array}{l}\text { Pre-Startup Safety Review } \\
\text { (PSSR) }\end{array}$ & $\begin{array}{l}\text { Employers must perform a PSSR for } \\
\text { new facilities and for modified facilities } \\
\text { when the modification is significant } \\
\text { enough to require a change in the process } \\
\text { safety information. Prior to the } \\
\text { introduction of a HHC to a process, the } \\
\text { PSSR must be confirmed that (1) } \\
\text { construction and equipment are in } \\
\text { accordance with design specifications; } \\
\text { (2) safety, operating, maintenance, and } \\
\text { emergency procedures are in place, } \\
\text { adequate and functioning; (3) a PHA has } \\
\text { been performed for new facilities and } \\
\text { recommendations have been resolved or } \\
\text { implemented before startup, the modified } \\
\text { facilities meet the management of } \\
\text { change requirements; and training of } \\
\text { each employee involved in operating a } \\
\text { process has been completed. }\end{array}$ \\
\hline Mechanical Integrity (MI) & $\begin{array}{l}\text { Employers must provide and implement } \\
\text { written mechanical integrity procedures } \\
\text { and programs to perform appropriate } \\
\text { maintenance and equipment inspection } \\
\text { and testing at proper frequencies to } \\
\text { discover equipment deficiencies before } \\
\text { they fail. Employees involved in } \\
\text { maintaining the integrity of process } \\
\text { equipment must be trained in the } \\
\text { procedures applicable to their job tasks. }\end{array}$ \\
\hline Hot Work Permit & $\begin{array}{l}\text { Employers must develop a hot work } \\
\text { permit program to prevent fires and } \\
\text { explosions possibly occur while } \\
\text { conducting hot work operations, e.g., } \\
\text { welding, cutting and grinding on or near } \\
\text { a covered process. The permit must } \\
\text { document that fire prevention and } \\
\text { protection measures are implemented } \\
\text { prior to begin hot work operations; it } \\
\text { must indicate the date authorized for hot } \\
\text { work; and identify the object on which } \\
\text { hot work is to be performed. The permit } \\
\text { must be kept on file until completion of } \\
\text { the hot work. }\end{array}$ \\
\hline $\begin{array}{l}\text { Management of } \\
\text { Change } \\
\text { (MOC) }\end{array}$ & $\begin{array}{l}\text { Employers must establish and implement } \\
\text { written procedures managing changes to, } \\
\text { for example, process chemicals, } \\
\text { technology, equipment, procedures to } \\
\text { facilities that affect a covered process } \\
\text { except for replacements in kind (RIK). } \\
\text { The employees involved must be trained } \\
\text { prior to startup of the process or startup } \\
\text { of the affected part of the process. If the }\end{array}$ \\
\hline
\end{tabular}




\begin{tabular}{|l|l|}
\hline \multicolumn{1}{|c|}{ Elements } & \multicolumn{1}{|c|}{ Requirements } \\
\hline & $\begin{array}{l}\text { MOC process affects PSI, PHA and OPs, } \\
\text { the employers must update or develop } \\
\text { the information to ensure all elements of } \\
\text { the PSM program are updated. }\end{array}$ \\
\hline $\begin{array}{l}\text { Incident Investigation } \\
\text { (II) }\end{array}$ & $\begin{array}{l}\text { Employers must investigate each } \\
\text { incident that resulted in, or could } \\
\text { reasonably have resulted in, a } \\
\text { catastrophic release of a HHC in the } \\
\text { workplace. Such an incident } \\
\text { investigation must be initiated as } \\
\text { promptly as possible, but not later than } \\
\text { 48 hours following the incident. To } \\
\text { understand the root causes that } \\
\text { contributed to the incident and to } \\
\text { develop the recommendations or to } \\
\text { follow up the corrective actions aiming } \\
\text { at prevention of the recurrence of the } \\
\text { incident, the investigation must be done } \\
\text { by the qualified investigation team. }\end{array}$ \\
\hline Trade Secrets (TS) & $\begin{array}{l}\text { Employers must develop and implement } \\
\text { emergency pre-planning and training to } \\
\text { make their employees aware of, and able } \\
\text { to execute proper actions. The } \\
\text { emergency plan contains emergency } \\
\text { notifications, response and reporting } \\
\text { procedures, escape routes, alarm } \\
\text { systems, and plant-wide training. In } \\
\text { addition, the emergency action plan must } \\
\text { include the procedures for handling } \\
\text { small releases of hazardous chemicals. }\end{array}$ \\
\hline Emergency Planning \\
and Response (EPR) \\
(CA)
\end{tabular}

\section{Effective PSM for HHCs}

An effective PSM for HHCs should be risk-based under the ALARP concept. Appropriate leading and lagging process safety metrics are recommended. Figure. 1 shows process safety metric pyramid [6]. Effective PSM implementation can prevent or mitigate the catastrophic incidents. The inclusive and integrated PSM intents, human factors, good design principles, recognized and generally accepted good engineering practices (RAGAGEPs), engineering and administrative controls, and integrity of operating and maintenance practices are substantial key roles. The commitment of top management and workforce involvement to specify process safety targets, implement PSM and evaluate the progress periodically is highly recommended.

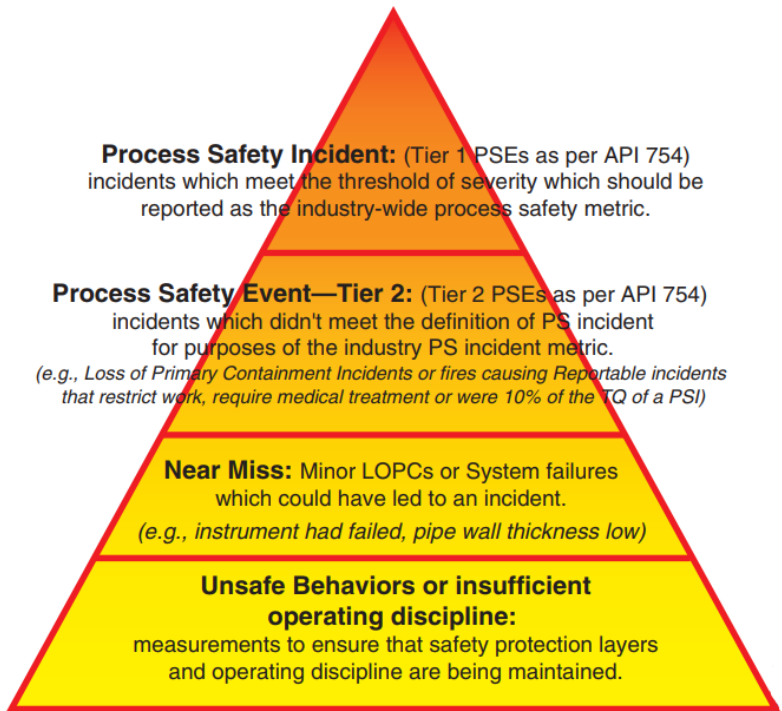

Fig. 1. Process Safety Metric Pyramid [6].

More noteworthy points of each element in Table 1 are shown as follows [1-7]:

All levels of employees shall participate in active PSM implementation, risk-based audit and continual improvement to achieve an incident- and injury-free workplace (EP).

The significant documents, e.g., PSI, PHA, OPs, PSSR, MI, MOC, II and EPR of the covered processes and other process safety requirements, if needed, must be controlled and reviewed to comply with the OSHA standard. All of the process safety related documents are plant-wide communication and are accessible to the employees involved.

Applicable recognized and generally accepted good engineering practices (RAGAGEPs) must be reviewed in PSI and MI. In general, RAGAGEPs are adopted in three provisions: (1) employers must document that all equipment in PSM-covered processes complies with RAGAGEPs (PSI); (2) inspections and tests are performed on process equipment subject to the standard's mechanical integrity requirements in accordance with RAGAGEPs (MI); and (3) inspection and test frequency follows manufacturer's recommendations and good engineering practice, and more frequently if indicated by operating experience (MI). RAGAGEPs are involved through asset life cycle from design, fabrication, installation, operation, maintenance and so on [8].

Integrity principles associated with process safety are design integrity, operational integrity, mechanical integrity (MI) or technical integrity and leadership integrity. Root causes of process safety incidents mainly come from lacking of design integrity, operational integrity and mechanical integrity. With respect to mechanical integrity of safety critical equipment (SCE), process monitoring and control systems, safety devices 
(e.g., alarms, interlocks, pressure relief and vent systems), emergency devices (e.g., emergency shutdown (ESD) system, shut-off valves), fire suppression systems must be regularly inspected.

The as low as reasonably practicable (ALARP) concept is defined as the concept that efforts to reduce risk should be continued until the incremental sacrifice (in terms of cost, time, effort, or other expenditure of resources) is grossly disproportionate to the incremental risk reduction achieved [1]. It is sometimes called as low as reasonably achievable (ALARA). ALARP is used in managing the risks of hazardous facilities as hazards and risks are not equal, and there are multiple risks and consequences to consider (PHA).

Engineering and administrative controls in PHA [9] are inevitable in particular for (1) hazards and their interrelationships such as prevention of exposures by applying detection methodologies to provide early warning of releases and identify actions required if exposure occurs, inventory control of HHCs, substitution of less hazardous materials, passive prevention and mitigation systems (e.g., monitors, deluge and foams), facility siting, reduced temperature and pressures, and redundant instruments. The consequences if engineering and administrative controls fail should be noted; and (2) safety and health considerations in the operating instructions of the OP.

Human factors addressed in PHA are concerned about operators and equipment interfaces, number and frequency of operator tasks, unusual work schedules, and the clarity and simplicity of controls, control displays, instructions, and signs. Human errors in design, operational works, mechanical works, instrumentation works, management, communication, decision making and planning, etc. are case basis [10-12].

About training and contractors, it is noted that the effective training programs for employees and contractors are layer of protection that helps ensure that employees and contractors have knowledge, skills and abilities to safely carry out their responsibilities for safe work operations. Operating procedures and process safety information are the foundation for process safety training.

Changes except for "replacements in kind" to process chemicals, technology, equipment, important software and procedures; and changes to facilities and utilities that affect a covered process shall be taken into account for management of change (MOC) and reviewed by knowledgeable team. Detailed training to all affected employees and contractors who are assigned specific roles within the MOC system shall be provided. Employees involved in operating a process and maintenance and contract employees whose job tasks will be affected by a change in the process shall be informed of and trained on the change prior to start-up of the process or that affected part of the process. For the change that is significant enough to require a change in the process safety information, pre-startup safety review (PSSR) is mandatory to ensure the readiness of safe operation.

Apart from the overall process safety metrics, an integrated set of leading and lagging process safety metrics related to incident investigation (II) should be ensured [6].

Although emergency planning and response (EPR), a passive protection, is the last defense mechanism of PSM implementation, it is significant. Emergency plans such as fire plan and drills are crucial. Fire safety systems must be in place, tested and inspected to verify that they are functioning. It is important that the required activities, e.g., emergency evacuation and emergency response are well-trained as intended, and knowledge of employees and contractors is sufficient. Ensure that the deficiencies found from drills compared with the original plan are recorded, reviewed and resolved.

Effective PSM audit is not only the compliance audit but it is risk-based and compliance audit (CA). Gap analysis against PSM mandatory requirements must be completely identified, and recommendations are noted. Supports by top management in terms of resources providing to close such identified gaps are necessary.

Finally, ensure that all important information related to process safety as well as best practices and lesson learned are available and accessible to those responsible employees for doing their designated tasks safely.

\section{PSM practices in Thailand}

As mentioned earlier PSM effectiveness depends on, for example, process safety metrics, management review, audit findings, particularly workforce involvement. In particular, PSM audit programs for both internal and external audits have proven the most important tool to recheck PSM performance. In Thailand, the Industrial Estate Authority of Thailand (IEAT) has regulated PSM and auditing in 2016 (so-called the Regulations of the Board of Directors of the Industrial Estate Authority of Thailand Governing Rules, Procedures and Conditions for Business Operations in Industrial Estates (No. 4) B.E. 2559) to the industries that locate in the industrial estates and have HHCs, flammable gases, liquids or the mixture of gas and liquid [13]. IEAT's PSM follows OSHA's 29 CFR 1910.119. Corresponding to a joint Memorandum of Understanding between the IEAT and the Engineering Institute of Thailand under H.M. the King's Patronage (EIT), an engineering profession and educational society, the integrity external audit programs based on the evidence-based were conducted through 9 pilot plants from 2014 to 2016 [14]. Recently, petrochemical plants, 
coal-fired power plants and gas separation plants had PSM external audits. Recommendations from audit findings indicate needs for improvements such as in engineering and administrative controls, and safeguards. The examples of drawbacks from those plants were: prioritizing productivity, product quality and costs rather than process safety; poor-defined process hazards or incomplete PHA; no specific checklist to identify human factors; outdated OPs; lack of design data of SCE and safety critical systems; poor integrity and inspection of SCE; inadequate training of employees and contractors; inadequate management of change; lack of testing of emergency measures; and weak internal audits. The systematic and critical review of PSM systems via the audits helps verify the PSM effectiveness. In other words, the effective audit and lesson learned can strengthen PSM effectiveness and continual improvement for the industries involved.

\section{Conclusion}

Effective and comprehensive process safety management is performance-based and therefore process safety metrics in terms of leading and lagging indicators of each element are often measured. Promising PSM may lead to low near miss, injuries and fatality rate. To achieve a successful PSM implementation, the commitment of top management, and employees' ownership and accountability are key success factors. Concern on deficiencies and recommendations lead to continual improvement in oil and gas industries as well as chemical and petrochemical plants.

\section{References}

[1] Available online at https://www.aiche.org/ccps/ resources/glossary.

[2] 29 CFR 1910.119, Process Safety Management of Highly Hazardous Chemicals; Final Rule; February 24, 1992, Federal Register Vol. 57, No. 36, pp. 6356-6417.

[3] U.S. Department of Energy. DOE Handbook: Process Safety Management for Highly Hazardous Chemicals. DOE-HDBK-1101-2004. 2004.

[4] Available online at https://www.osha.gov/pls/ publications/publication.athruz?pType $=$ Industry $\&$ pID=166 (OSHA 3132-2000; OSHA 3133-1994; DOE-HDBK-1100-2004; OSHA 3909-2017).

[5] U.S. Department of Energy. DOE Handbook: Chemical Process Hazards Analysis. DOEHDBK-1100-2004. 2004.

[6] CCPS. Process Safety Leading and Lagging MetricsYou Don't Improve What You Don't Measure. 2011.

[7] Louvar, J.F. and Louvar, B.D. Health and Environmental Risk Analysis: Fundamentals with Applications. $2^{\text {nd }}$ ed. Upper Saddle River, NJ,
Prentice Hall, 1998.

[8] RAE Engineering and Inspection Ltd. "Total Asset Integrity Management". Available online at https://www.raeengineering.ca/services/area-ofpractice/asset-integrity-management/total-assetintegrity-management/.

[9] Nigel Hyatt. Guidelines for Process Hazards Analysis, Hazards Identification \& Risk Analysis. CRC Press LLC. 2003.

[10] CCPS. Guidelines for Preventing Human Error in Process Safety. 1994.

[11] Janette Edmonds, Editor. Human Factors in the Chemical and Process Industries. Elsevier. 2016.

[12] J. Robert Taylor. Human Error in Process Plant Design and Operations. CRC Press. 2016.

[13] Industrial Estate Authority of Thailand (IEAT). The Regulations of the Board of Directors of the Industrial Estate Authority of Thailand Governing Rules, Procedures and Conditions for Business Operations in Industrial Estates (No. 4) B.E. 2559 (2016) (In Thai), 2016.

[14] Sommani P. and Lothongkum A.W. Challenges of Process Safety Management Audit in Thailand. Asia Pacific Symposium on Safety 2017 (APSS 2017), Kitakyushu, 2017, SB4-02. 